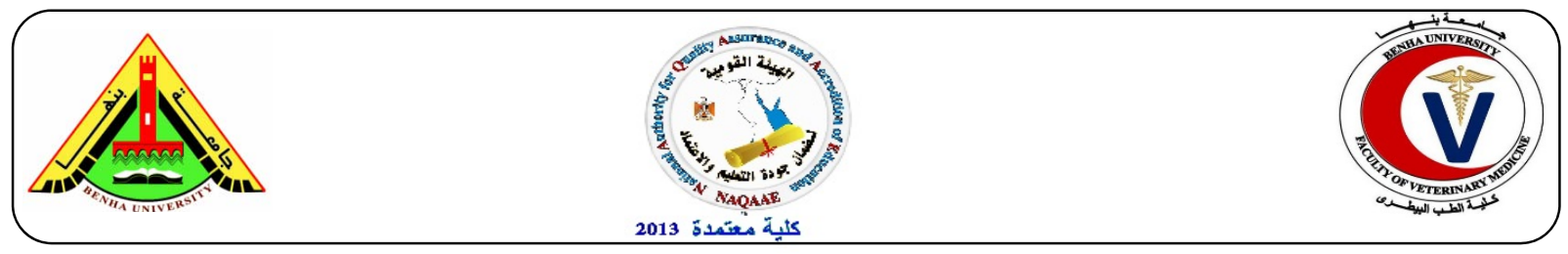

\title{
Environmental Contamination with Methicillin Resistant Staphylococci in Food animal carcasses.
}

\author{
Amani, M. Salem ${ }^{1}$; Zakaria, E.M. ${ }^{2}$; Abd EI Raheem, K.A. ${ }^{1}$ \\ ${ }^{1}$ Faculty of Veterinary Medicine, Benha University, Egypt \\ ${ }^{2}$ Animal Health Research Institute, Dokki, Egypt
}

\section{A B S T R A C T}

One hundred random samples of cattle and sheep meat, equipment and workers hands swabs (25 samples of each) were collected from different abattoirs in Kalyobia governorates. The obtained results indicated that the mean values of APC, and $S$. aureus counts in the examined samples were $1.5 \times 10^{4} \pm 0.9 \times 10^{4}, 1.77 \times 10^{3} \pm 1 \times 10^{3} \mathrm{CFU} / \mathrm{g}$ for cattle meat, $1 \mathrm{x}$ $10^{4} \pm 0.65 \times 10^{4}, 1.57 \times 10^{5} \pm 0.83 \times 10^{5} \mathrm{CFU} / \mathrm{g}$ for sheep meat, $7.4 \times 10^{3} \pm 0.29 \times 10^{4}, 1.1 \times 10^{3} \pm 0.33 \times 10^{3} \mathrm{CFU} / \mathrm{g}$ for equipment swab and $5.77 \times 10^{3} \pm 0.3 \times 10^{4}, 7.4 \times 10^{3} \pm 0.49 \times 10^{4} \mathrm{CFU} / \mathrm{g}$, for workers hands swab, respectively. The incidence of S. aureus was $52 \%, 48 \%, 56 \%$ and $64 \%$ in the examined samples of cattle and sheep meat, equipments and workers hands swabs, respectively. On the other hand, Methicillin Resistant S. aureus (MRSA) was isolated from 32\%, $24 \%, 40 \%$ and $44 \%$ of the examined samples of cattle and sheep meat, equipments and workers hands swab respectively. The significance of the isolated bacteria in the examined animal carcasses at abattoir level and possible sources of contamination as well as some recommendations to improve the quality of these carcasses were discussed.

Keywords: Meat, Abattoir, S. aureus, MRSA., Carcass

(http://www.bvmj.bu.edu.eg)

(BVMJ-32(1): 170-176, 2017)

\section{INDRODUCTION}

During slaughtering of animals, contamination of carcasses and the environment with MRSA may occur and consequently meat of these animals may get contaminated. Thus MRSA strains have been detected in different foods, including meat products (van Loo et al., 2007). Also, the workers hand and the equipment were the main source of carcass contamination inside the abattoir (Ali, 2007). Staphylococcus aureus is a cause of many diseases in both humans and animals. This pathogen so a major target in the screening of the slaughterhouse carcasses to monitor hygienic conditions during slaughter. Methicillin resistant staphylococcus aureus (MRSA) infections have become a public health concern in both communities and hospitals, so testing for presence of MRSA in animal carcasses during slaughtering operations is warranted. Most animals may be colonized with $S$. aureus but only recently MRSA strains were isolated from several food production animals, including cattle, sheep, chicken and other animals (Deneeling et al., 2007). WHO, United Nations Food, Agriculture Organization and the World Organization for Animal Health concluded that there is a clear evidence of adverse human health consequences due to resistant organisms (such as MRSA) resulting from non-human usage of antimicrobials. These consequences include increase frequency of treatment failures, increase severity of infections and death in some cases (Ganguly et al., 2011). Also, the cost of treatment of such cases is high (U.S. Congress, 2011). So, it is important to monitor the prevalence and antimicrobial resistance of food borne pathogens for effective food safety planning and targeted interventions (Nguyen et al., 2012). In addition, there is no available data in Egypt concerning the prevalence of Methicillin resistant staphylococcus aureus (MRSA) at abattoir level.

Therefore, the goal of this work was planned to investigate the Incidence of Methicillin resistant staphylococcus aureus (MRSA) contamination at abattoir level.

\section{MATERIAL AND METHODS}

\subsection{Collection of samples:}

One hundred random samples of cattle and sheep meat \& equipment and workers hands swabs (25 of each) were collected from Kalyobia 
abattoirs. The collected meat samples were transferred in separate sterile plastic bags directly to the laboratory in an ice box under complete aseptic conditions without undue delay, to be examined bacteriologically. Swabs were taken after complete dressing of slaughtered animals and then placed into ice box, transferred immediately to the laboratory without delay and under aseptic condition.

\subsection{Preparation of samples:}

Preparation of meat samples: according to ("APHA"American Public Health Association, 2001). Preparation of swab samples: according to (Food Safety and Inspection service "FSIS", 1996).

\subsection{Determination of aerobic plate count: according to ("ICMSF" International commission of Microbiological Specification for Foods, 1996), 1996).}

2.4. Determination of Staphylococcus aureus count: according to ((Food safety and Drug administration (FDA), 2001).

\subsection{Isolation and Identification of Staphylococcus aureus:}

Morphologically, Biochemically and Serologically. Morphological examination: according to (Cruickshank et al., 1975). Biochemical Identification: according to (FDA, 2001). Serological Identification: according to (Oxoid, 1990): Staphylase (using oxoid dry spot staphtect plus kit) is are liable latex slide agglutination test for detection a wide range of Staph. aureus strains.

\subsection{Isolation and Identification of Methicillin resistant staphylococcus aureus: (Heuvelink et al., 2009)}

culture media: Enrichment broth: - MuellerHinton broth (Oxoid, 1990) with added 6.5\% sodium chloride $(\mathrm{MHB}+6.5 \% \mathrm{NaCl})$. phenol red mannitol broth containing ceftizoxime $(5 \mu \mathrm{g} / \mathrm{ml})$ and aztreonam (75 $\mu \mathrm{g} / \mathrm{ml})$ (PHMB). Isolating media: MRSA ID agar (bioMérieux), Brain Heart Infusion (BHI) broth (Oxoid) and Tryptone Soya Agar (TSA) (Oxoid, 1990). Detection method: A quantity of approximately $25 \mathrm{~g}$ of meat was introduced into nine times its volume of the enrichment broth $\mathrm{MHB}+6.5 \% \mathrm{NaCl}$ and homogenized. The suspension was incubated for $16-20 \mathrm{~h}$ at $37{ }^{\circ} \mathrm{C}$. An amount of $1 \mathrm{ml}$ of the enriched $\mathrm{MHB}+6.5 \% \mathrm{NaCl}$ was added to $9 \mathrm{ml}$ of PHMB + , followed by incubation for $16-20 \mathrm{~h}$ at 37
${ }^{\circ} \mathrm{C}$. From the culture obtained in $\mathrm{PHMB}+$ the surface of the selective isolation medium MRSA ID was inoculated with a sterile loop. The plates were incubated for $24 \mathrm{~h}$ at $37^{\circ} \mathrm{C}$ and when the colonies were difficult to identify the incubation was extended for another $24 \mathrm{hrs}$. The plates were examined for typical green colonies. For confirmation a maximum of 5 selected typical colonies per plate were sub cultured on TSA. Typical colonies were tested with the Staphytect Plus test (Oxoid), a latex agglutination test for the detection of clumping factor, Protein A and certain polysaccharides found in MRSA.

\subsection{Statistical Analysis:}

The obtained results were statistically evaluated by application of Analysis of Variance (ANOVA) test according to Feldman et al. (2003).

\section{RESULTS}

It is evident from the results recorded in Table (1) that the APC of the examined samples of the cattle meat ranged from $1.2 \times 10^{3}$ to $4.6 \times 10^{4}$ $\mathrm{CFU} / \mathrm{g}$ with an average of $1.5 \times 10^{4} \pm 0.9 \times 10^{4}$ $\mathrm{CFU} / \mathrm{g}, 1.7 \times 10^{3}$ to $3.6 \times 10^{4} \mathrm{CFU} / \mathrm{g}$ with an average of $1 \times 10^{4} \pm 0.65 \times 10^{4} \mathrm{CFU} / \mathrm{g}$ in sheep meat, $2.1 \times 10^{2}$ to $1.8 \times 10^{4} \mathrm{CFU} / \mathrm{g}$ with an average of $7.4 \times 10^{3} \pm 0.29 \times 10^{4} \mathrm{CFU} / \mathrm{g}$ in equipment's swabs and $7.7 \times 10^{2}$ to $1.8 \times 10^{4} \mathrm{CFU} / \mathrm{g}$ with an average of $5.77 \times 10^{3} \pm 0.3 \times 10^{4} \mathrm{CFU} / \mathrm{g}$ in workers hands swab.

Results as shown in Table (2) revealed that the higher values of Staph. aureus count recorded in sheep meat samples that ranged from $5.8 \times 10^{3}$ to $4.3 \times 10^{5} \mathrm{CFU} / \mathrm{g}$ with an average of $1.57 \times 10^{5} \pm$ $0.83 \times 10^{5} \mathrm{CFU} / \mathrm{g}$, Moreover, that in the cattle meat samples were ranged from $1.1 \times 10^{2}$ to $5.6 \times 10^{3}$ $\mathrm{CFU} / \mathrm{g}$ with an average of $1.77 \times 10^{3} \pm 1 \times 10^{3}$ $\mathrm{CFU} / \mathrm{g}, 5.7 \times 10^{2}$ to $2.4 \times 10^{3} \mathrm{CFU} / \mathrm{g}$ with an average of $1.1 \times 10^{3} \pm 0.33 \times 10^{3} \mathrm{CFU} / \mathrm{g} 1.1 \times 10^{3}$ to $2.7 \times 10^{4} \mathrm{CFU} / \mathrm{g}$ with an average of $7.4 \times 10^{3} \pm$ $0.49 \mathrm{x} 10^{4} \mathrm{CFU} / \mathrm{g}$ in equipment and workers hands swabs, respectively.

Table (3) revealed that the incidences of Staph. aureus was $52 \%, 48 \%, 56 \%$ and $64 \%$ in the examined samples of cattle and sheep meat, equipment and workers hands swabs, respectively. Results given in table (4) and revealed that the incidences of Methicillin Resistant Staphylococcus aureus (MRSA) were $32 \%, 24 \%, 40 \%$ and $44 \%$ in the examined samples of cattle and sheep meat, equipment and workers hands swabs, respectively. 
Table (1): Mean values of APC count (CFU/g) in the examined samples of cattle and sheep meat, equipment and workers hands swabs at abattoir level. $(\mathrm{No}=25)$

\begin{tabular}{lccc}
\hline \multicolumn{1}{c}{ Samples } & Min. & Max. & Mean \pm S.E \\
\hline 1- Cattle meat & $1.2 \times 10^{3}$ & $4.6 \times 10^{4}$ & $1.5 \times 10^{4} \pm 0.9 \times 10^{4}$ \\
2- Sheep meat & $1.7 \times 10^{3}$ & $3.6 \times 10^{4}$ & $1 \times 10^{4} \pm 0.65 \times 10^{4}$ \\
3- Equipment's swabs & $2.1 \times 10^{2}$ & $1.8 \times 10^{4}$ & $7.4 \times 10^{3} \pm 0.29 \times 10^{4}$ \\
4-Workers hands swabs & $7.7 \times 10^{2}$ & $1.8 \times 10^{4}$ & $5.77 \times 10^{3} \pm 0.3 \times 10^{4}$ \\
\hline
\end{tabular}

There is non-significant difference between samples

Table (2): Mean values of Staph. aureus count (CFU/g) in the examined samples of cattle and sheep meat, equipment and workers hands swabs at abattoir level. $(\mathrm{No}=25)$

\begin{tabular}{lccc}
\hline \multicolumn{1}{c}{ Samples } & Min. & Max. & Mean \pm S.E \\
\hline 1- Cattle meat & $1.1 \times 10^{2}$ & $5.6 \times 10^{3}$ & $1.77 \times 10^{3} \pm 1 \times 10^{3 \mathrm{a}}$ \\
2- Sheep meat & $5.8 \times 10^{3}$ & $4.3 \times 10^{5}$ & $1.57 \times 10^{5} \pm 0.83 \times 10^{5 \mathrm{~b}}$ \\
3- Equipment's swabs & $5.7 \times 10^{2}$ & $2.4 \times 10^{3}$ & $1.1 \times 10^{3} \pm 0.33 \times 10^{3 \mathrm{a}}$ \\
4-Workers hands swabs & $1.1 \times 10^{3}$ & $2.7 \times 10^{4}$ & $7.4 \times 10^{3} \pm 0.49 \times 10^{4 \mathrm{a}}$ \\
\hline
\end{tabular}

Values with different letters within the same column differed significantly at $p \leq 0.05$.

Table (3): Incidence of Staph. aureus in the examined samples of cattle carcass and sheep meat, equipment and workers hands swabs. $(\mathrm{No}=25)$

\begin{tabular}{lcccccccc}
\hline \multicolumn{1}{c}{ Samples } & \multicolumn{2}{c}{ Cattle } & \multicolumn{2}{c}{ Sheep } & \multicolumn{2}{c}{ Equipment's swabs } & \multicolumn{2}{c}{ Workers hands swabs } \\
meat & \multicolumn{2}{c}{ meat } & & & \\
M.O & No & $\%$ & No & $\%$ & No & $\%$ & No & $\%$ \\
\hline S. aureus & 13 & 52 & 12 & 48 & 14 & 56 & 16 & 64 \\
\hline
\end{tabular}

Table (4): Incidence of Methicillin Resistant Staphylococcus aureus (MRSA) isolated from the examined samples of cattle and sheep meat, equipment and workers hands swabs at abattoir level. $(\mathrm{No}=25)$

\begin{tabular}{lccccccccc}
\hline \multicolumn{1}{c}{ Samples } & \multicolumn{2}{c}{$\begin{array}{c}\text { Cattle } \\
\text { meat }\end{array}$} & \multicolumn{2}{c}{$\begin{array}{c}\text { Sheep } \\
\text { meat }\end{array}$} & \multicolumn{2}{c}{ Equipment's swabs } & \multicolumn{2}{c}{$\begin{array}{c}c \\
\text { Sorkers hands }\end{array}$} \\
M.O & No & $\%$ & No & $\%$ & No & $\%$ & \multicolumn{2}{c}{ No } & $\%$ \\
\hline Methicillin Resistant S. Aureus (MRSA) & 8 & 32 & 6 & 24 & 10 & 40 & 11 & 44 \\
\hline
\end{tabular}

\section{DISCUSSION}

There are no significant differences between APC in the examined samples. This might be due to the same environment and procedures under which the animals were slaughtered and handled in the abattoir. The obtained results of APC of the examined samples of cattle and sheep meat, equipment and workers hands swabs come in accordance with those reported by El-Dally (1994) $\left(4.7 \times 10^{3} \mathrm{CFU} / \mathrm{g}\right) \&$ Gill et al. (2000) $\left(4.4 \times 10^{4}\right.$ CFU /g) \& Duffy et al. (2001) $\left(2.6 \times 10^{4} \mathrm{CFU} / \mathrm{g}\right)$ \& Kahraman et al. (2005) $\left(1.5 \times 10^{4} \mathrm{CFU} / \mathrm{g}\right) \&$ Martinez et al. (2009) (1.12x $\left.10^{4} \mathrm{CFU} / \mathrm{g}\right) \&$ Feizullah and Daskalov (2010) $\left(1.2 \times 10^{4} \mathrm{CFU} / \mathrm{g}\right)$ \& Mohamd-Eman (2015) $\left.\left(9.28 \times 10^{4} \mathrm{CFU} / \mathrm{g}\right)\right)$.
While, lower results were recorded by Biss and Hathaway (1995) $\left(2.8 \times 10^{2} \mathrm{CFU} / \mathrm{g}\right) \&$ Sumner et al. (2003) (6.6 x 10 CFU /g) \& Yalcin et al. (2004) $\left(1.9 \times 10^{2} \mathrm{CFU} / \mathrm{g}\right) \&$ Pearce and Bolton (2005) and Pearce and Bolton (2005) $\left(1.58 \times 10^{2} \mathrm{CFU} / \mathrm{g}\right) \&$ Abdallah et al. (2010) $\left.\left(6.2 \times 10^{2} \mathrm{CFU} / \mathrm{g}\right)\right)$. However higher findings were obtained by Ishak (1992) $\left(9 \times 10^{5} \mathrm{CFU} / \mathrm{g}\right)$, Mukhoopadhyay et al. (1988) $\left(1.2 \times 10^{8} \mathrm{CFU} / \mathrm{g}\right)$ and Shaltoot (2001) (6.1 x $\left.10^{5} \mathrm{CFU} / \mathrm{g}\right)$.

Slaughtering process involves many risks of carcass contamination either directly or indirectly. Fecal contamination and subsequent contamination of the carcass may occur (Edwards (Edwards et al., 1997) et al, 1997). 
The higher incidence of the microbial contamination in the carcasses might be attributed to unhygienic and improper handling of animals during slaughtering, dressing and evisceration. The differences between mean values of Staph. aureus counts in the examined samples were significant $(P$ $<0.05)$.

The obtained results of the mean values of $\mathrm{S}$. aureus counts of the examined samples of cattle and sheep meat, equipment and workers hands swabs agreed with those reported by Ishak (1992) $\left(2.8 \times 10^{3} \mathrm{CFU} / \mathrm{g}\right) \&$ Abd El-Aziz (1997) $(2.8 \times$ $\left.10^{3} \mathrm{CFU} / \mathrm{g}\right) \&$ El-Taher-Amna (2009) $\left(4.16 \times 10^{3}\right.$ CFU /g) \& Salama (2013) (7.2 x 10 $0^{3}$ CFU /g) \& Mohamd-Eman (2015) (1.56 x $\left.10^{3} \mathrm{CFU} / \mathrm{g}\right)$ ). While, higher results were recorded by Arab (2010) $\left(6.2 \times 10^{6} \mathrm{CFU} / \mathrm{g}\right)$ and Magdy (2014) (2.8 x $\left.10^{4} \mathrm{CFU} / \mathrm{g}\right)$.

Staphylococcus aureus is a cause of many diseases in both humans and animals. The total Staphylococcal count so a major target in the screening of the slaughterhouse carcasses to monitor hygienic conditions during slaughter (Potter, 2001). The higher mean values of staph. aureus count in the examined sheep carcass samples might be due to dirties and fecal matters that present on the wool (Biss and Hathaway, 1995) and subsequent contamination occurred by workers hand, equipment and environmental surfaces (Ali, 2007; Arnold and Silvers, 2000; USFDA (U.S. Food and Drug Admistration), 2012).

Concerning the incidence of Staph. aureus, the results obtained in this study were agreed with those obtained by Peel et al. (1975) (57\%) \& De Wit and Kampelmacher (1981) (65\%) \& Desmarcheller et al. (1999) (40\%) \& Acco et al. (2003) $(30 \%) \&$ van Loo et al. (2007) $(45 \%) \&$ Mai-Siyama et al. (2014) (41.1\%). While lower results were recorded by Han et al. (2009) (20\%) \& Tassew et al. (2010) (12.1\%) \& Zhang et al. (2011) (20\%).

The higher incidence of Staph. aureus contamination of the animal carcasses in this study might be due to unhygienic practices, improper handling during slaughtering, uncleaned environmental surfaces and untrained workers. The Staphylococci exist in air, dust, sewage, food, food equipment and environmental surfaces. Humans and animals are the primary reservoirs. Staphylococci are present in the nasal passages, throat, hair and skin of about $50 \%$ of healthy individuals. Although food handlers are usually the main source of food contamination in food poisoning outbreaks, equipment and environmental surfaces can also be sources of $S$. aureus contamination (USFDA (U.S. Food and Drug Admistration), 2012).
Also, 65 to $100 \%$ of the hands of workers in slaughterhouses were contaminated with Staphylococcus aureus. It is proposed that the hands of those workers contributed to the contamination of the carcasses and account for the increase observed after evisceration (De Wit and Kampelmacher, 1981).

The presence of Staphylococcus aureus on bovine carcasses surfaces may be due to contamination during dressing and evisceration in the slaughterhouse, contaminated equipment, butcher's hands with abrasions and wounds, slaughter of animal beside dressed one in the same area in the slaughter hall, contaminated air with Staphylococcus aureus can be expected (Lasta et al., 1992).

Concerning the incidence of Methicillin Resistant Staph. aureus, the results obtained in this study agreed with those obtained by Jackson et al. (2013) (63\%) \& Mai-Siyama et al. (2014) (21.8\%) and Pexara et al. (2013) (high MRSA contamination level of cattle meat in Asia and Africa). While lower results recorded by van Loo et al. (2007) (2.5\%) \& Han et al. (2009) (0.8\%) \& Weese et al. (2010) (5.6\%) \& Zhang et al. (2011) $(1.3 \%))$. To the best of our knowledge, this is the first report in Egypt of Methicillin Resistant Staphylococcus aureus (MRSA) colonization rate among slaughtered animals, contact persons and surrounding environment at abattoir level.

Based on finding of this study, we can state that the prevalence of Methicillin Resistant Staphylococcus aureus (MRSA) in the meat, equipment and contact persons in abattoir might be assumed to be relatively high for geographical location without any pre-existing epidemiological data for comparison. The reason being that these resistant strains and genes can be transmitted and disseminated between human and animals and subsequently into the food chain. The level of contamination of animals with Methicillin Resistant Staphylococcus aureus (MRSA) isolates varies with geographical location, as low contamination level reported in European countries, the USA and Canada in contrast to high contamination level reported in Asia and Africa (Pexara et al., 2013).

The Methicillin Resistant Staphylococcus aureus (MRSA) colonization of cattle posed a potential risk of up to $60 \%$ transmission to the contact persons (Lee, 2003). The most of the nosocomial Staphylococcus aureus infections are caused by Methicillin Resistant Staphylococcus aureus (MRSA) strains and have become a widely recognized cause of morbidity and mortality throughout the world (Pesavento et al., 2007).

From the point of high prevalence of 
Staphylococcal contamination in animal carcasses, environmental surfaces and contact persons in this study subsequently high prevalence of MRSA contamination in them. This might be due to during slaughtering of MRSA positive animals, contamination of carcasses and the environment with MRSA may occur and consequently meat of these animals may get contaminated (van Loo et al., 2007).

In Egypt the available data on the LA-MRSA prevalence rate, predisposing risk factors and transmission between humans and animals are scare. Therefore, epidemiological information on MRSA pathogens is imperative, as it will provide a base line information needed for control, prevention and its overall public health implication in the community.

In conclusion, the higher prevalence of MRSA strains in this study is demonstrating the fast growing and alarming situation to public health system and the community. So it requires strong controlling system of the personal hygiene and educating food handlers about the basic ideas of food processing, environmental hygiene and sanitation to produce safe food. In addition, consumers should avoid eating and raw inadequately cooked food.

\section{REFERENCES}

"APHA"American Public Health Association, 2001. Compendium of methods for the microbiological examination of food. $4^{\text {th }} \mathrm{Ed}$ Washington D., USA.

"ICMSF" International commission of Microbiological Specification for Foods, 1996. Microorganisms in Food. I-Their Significance and methods of enumeration. . $3^{\text {rd }} \mathrm{Ed}$. Univ. of Toronto, Canada.

Abd El-Aziz, A.S., 1997. Quality assurance of a new locally produced beef meat product. Vet. Med. J. Giza 45, 345.

Abdallah, M.A., Suliman, S.E., Bakhiet, A.O., 2010. Method for reducing contamination of indigenous cattle carcasses during slaughtering. Assiut Vet. J. 56, 86-93.

Acco, M., Ferreira, F., Henriques, J., Tondo, E., 2003. Identification of multiple strains of Staphylococcus aureus colonizing nasal mucosa of food handlers5. Food Microbiology5 205, 489-493.

Ali, A.A., 2007. Prevalence of bacterial contamination of public health concern on bovine carcasses at Khartoum state. Sudan. M.S.CV. Thesis Sudan University of Science and Technology, Sudan.
Arab, W.S.S., 2010. Quality improvement of meat meals provided by a University Student Restaurant. PhD. thesis, Meat Hygiene, Fac. Vet., Benha Univ.

Arnold, J.W., Silvers, S., 2000. Comparison of poultry processing equipment surfaces for susceptibility to bacterial attachment and biofilm formation. Poult Sci 79, 1215-1221.

Biss, M.E., Hathaway, S.C., 1995. Microbiological and visible contamination of lamb carcasses to preslaughter presentation status: implication of HAACP. J. Food Protect. 85, 776-778.

Cruickshank, R., Duguid, J., Marmion, B., Olkkonen, L., Swain, R., 1975. The practice of medical microbiology. $12^{\text {th }}$ Ed., Churchill Livingstone, Edinburg.

De Wit, J., Kampelmacher, E.H., 1981. Some aspects of micropial contamination of hands of workers in food industries. Zb. Bakt. Hyg. I. Abst. Orig. B172, 390-400.

Deneeling, A.J., Van den Broeek, M.J.M., Spalburg, E.C., van Santen-Verheuvel, M.G., Dam-Deisz, W.D.C., Boshuizen, H.C., van de Giessen, A.W., van Duijkeren, E., Huijsdens, X.W., 2007. High prevalence of methicillin resistant staphylococcus aureus in pigs. Vet. Microbiol. 122, 366372.

Desmarcheller, P.M., Higges, G.M., Hills, L., Sullivan, A.M., Vanderlinde, P.B., 1999. Incidence of coagulase positive staphylococcus on beef carcasses in three Australian abattoirs. Inter. J. Food Microbiol. 137, 88-100.

Duffy, E.A., Belk, K.E., Sofos, J.N., LeValley, S.B., Kain, M.L., Tatum, J.D., Smith, G.C., Kimberling, C.V., 2001. Microbial contamination occurring on lamb carcasses processed in the United States. J Food Prot 64, 503-508.

Edwards, D.S., Johnston, A.M., Mead, G.C., 1997. Meat inspection: an overview of present practices and future trends. Vet J 154, 135147.

El-Dally, K.M.A., 1994. Correlation between parasitism and microbial load and meat quality of the Egyptian food animals. PhD. Meat Hygiene, Fac. Vet. Med. Zagazig Univ. .

El-Taher-Amna, M., 2009. Impact of temperature abuse of safety of food offered in an University Student Restaurant. M.V.Sc. Thesis, Meat Hygiene, Fac. Vet. Med. Benha Univ.

Feizullah, F., Daskalov, H., 2010. Investigation on lamb meat production hygiene in facilities 
with low and high production capacity. Bulg. J. Vet. Med. 13, 252-258.

Feldman, D., Ganon, J., Haffman, R., Simpson, J., 2003. The solution for data analysis and presentation graphics. $2^{\text {nd }}$ Ed., Abacus Lancripts, Inc., Berkeley, USA.

Food safety and Drug administration (FDA), 2001. U.S Food and Drug Administration. Bacteriological Analytical Manual Online.

Food Safety and Inspection service "FSIS", 1996. United states Department of Agriculture. Pathogen Reduction; Hazard Analysis and Critical Control Point (HACCP) systems; Final Role. Federal Register 61.

Ganguly, N.K., Arora, N.K., Chandy, S.J., Fairoze, M.N., 2011. Rationalizing antibiotic use to limit antibiotic resistance in india. Indian $\mathrm{J}$. Vet. Med. 134, 281-294.

Gill, C.O., Bryan, J., Brereton, D.A., 2000. Microbiological conditions of sheep carcasses from conventional or inverted dressing process. J. Food Protect. 63, 12911294.

Han, F., Pu, S., Ge, B., 2009. Isolation and characterization of methicillin resistant $\mathrm{S}$. aureus strains from Louisiana retail meats. Appl Environ. Microbiol. 75, 265-267.

Heuvelink, A.E., Zwarthruis-Nahuis, J.T., Wit, B.H., X.W. , De Neeling, A.G., 2009. Prevalence of methicillin resistant staphylococcus aureus in meat. Int. J. Food Microbiol. 31, 52-56.

Ishak, F.B., 1992. Sanitary status of cattle livers in Sharkia province. M.V.Sc. Thesis, Meat Hygiene, Fac. Vet. Med. Zagazige Univ.

Jackson, C.R., Davis, J.A., Barrett, J.B., 2013. Prevalence and characterization of methicillin-resistant Staphylococcus aureus isolates from retail meat and humans in Georgia. J Clin Microbiol 51, 1199-1207.

Kahraman, T., Buyukunal, S.K., Cetin, O., 2005. Microbiological contamination of lamb carcasses at abattoirs of Istanbul. Vet. Glasnik 59, 437-444.

Lasta, L.A., Radriguez, R., Zanelli, M., Morgaria, A., 1992. Bacterial count from bovine carcasses as an indicator of hygiene at slaughtering places. A proposal for sampling. J. Food Protect. 54, 271.

Lee, J.H., 2003. Methicillin (oxacillin)-resistant Staphylococcus aureus isolated from major food animals and their potential transmission to humans. Appl. Environ. Med. Microbiol. 69, 6489-6494.

Magdy, S.M.E., 2014. Food safety of cattle meat and offal at abattoir level. M.V.Sc. Thesis, Meat Hygiene, Fac. Vet. Med. Benha Univ.
Mai-Siyama, I.B., Okon, K.O., Adamu, N.B., Askira, U.M., Isyaka, T.M., Adamu, S.G., Mohammed, A., 2014. MRSA colonization rate among ruminant animals slaughtered for human consumption and contact persons in Maidguri, Nigeria. African J. Microbial. Research 8, 2643-2649.

Martinez, B., Celda, M.F., Millan, M.E., Espacio, A., Cano, M., Lopez-Mendoz, M.C., 2009. Assessment of the microbiological conditions of red meat carcasses from bacterial counts recovered by sampling via excision or swabbing with cotton wool. Inter. J. Food Sci. Technol. 44, 770-776.

Mohamd-Eman, H.S., 2015. Improvement of Microbiological State of Menofia Abattoirs. M.V.Sc. Thesis, Meat Hygiene, Fac. Vet. Med. Benha Univ.

Mukhoopadhyay, H.K., Puvarian, B., Dorairajan, N., 1988. Detection of microbial load in flesh mutton and its impact to public health. Ind. J. Ani. Hlth. 64, 81-83.

Nguyen, H.N., Smooker, P.M., Coloe, P.J., 2012. The antibiotic resistance characteristics of non typhoidal Salmonella Enterica isolated from food producing animals, retail meat and humans in South East Asia. Int. J. Food Microbiol. 154, 98-106.

Oxoid, 1990. Culture media, ingredients and other laboratory services. $9^{\text {th }}$ Ed. Published by Oxoid, Limited, London.

Pearce, R.A., Bolton, D.J., 2005. Excision via sponge swabbing - acomparison of methods for the microbiological sampling of beef, pork and lamb carcasses. Int. J. Food Microbiol. 75, 85 .

Peel, B., Bothwell, S.J., Simmons, G.C., Frost, A., 1975. A study of the the number and phage patterns of S,aureus in abaatoirs. Australian Vet. J. 51, 126.

Pesavento, G., Ducci, B., Comodo, N., Nostro, A.L., 2007. Antimicrobial resistance profile of S. aureus isolates from raw meat: a research for MRSA. Food Control 18, 196200.

Pexara, A., Solomakos, N., Govaris, A., 2013. Prevalence of Methicillin resistant Staphylococcus aureus (MRSA) in animals in Nigeria. J. Hellenci Vet. Med. Soc. 64, 1734

Potter, N.N., 2001. Food Science. $3^{\text {rd }}$ Ed., the AVI publishing Co. Inc. New York.

Salama, E.A., 2013. Sanitary conditions of cattle and camel carcasses at Menofia abattoirs. PhD., Thesis, Meat Hygiene, Fac. Vet. Med. Benha Univ. . 
Shaltoot, F.A., 2001. Quality evaluation of sheep carcasses slaughtered at Kalyobia abattoirs. Assuit Vet. Med. J. 46, 150-159.

Sumner, J., Petrenas, E., Dean, P., Dowsett, P., West, G., Wiering, R., Raven, G., 2003. Microbial contamination on beef and sheep carcasses in South Australia. Inter. J. Food Microbiol. 81, 225.

Tassew, H., Abdissa, A., Beyene, G., GebreSelassie, S., 2010. Microbial Flora and Food Borne pathogens on Minced Meat and their Susceptibility to Antimicrobial Agents. J. Home 20.

U.S. Congress, 2011. Preservation of antibiotics for medical treatment act of 2011. $112^{\text {th }}$ Congress 2011-2013. Publishing Govtrack Web.

USFDA (U.S. Food and Drug Admistration), 2012. Bad Bug Book: Foodborne pathogenic Micro-organisms and Natural toxins Hand book S.aureus. 10903 New Hampshire Avenue Silver Spring, MD 20993. van Loo, I.H., Diederen, B.M., Savelkoul, P.H., Woudenberg, J.H., Roosendaal, R., van Belkum, A., Lemmens-den Toom, N., Verhulst, C., van Keulen, P.H., Kluytmans, J.A., 2007. Methicillin-resistant Staphylococcus aureus in meat products, the Netherlands. Emerg Infect Dis 13, 17531755.

Weese, J.S., Avery, B.P., Reid-Smith, R.J., 2010. Detection and qualification of Methicillinresistant Staphylococcus aureus (MRSA) clones in retail meat products. Lett. Appl Microbiol. 51, 338-342.

Yalcin, S., Nizamlioglu, Gurbuz, U., 2004. Microbiological conditions of sheep carcasses during the slaughtering process. J. Food Safety 24, 87-93.

Zhang, Y., Kanika, B., W.;, X., Susan, D.P., Marcus, Z., 2011. Methicillin-resistant Staphylococcus aureus in Retail meat, Detroit, Michigan, USA. Emerging Infecctions Diseases 17, 1135-1137. 